\title{
Seismic Behaviour of Strengthened Unreinforced Masonry Walls using Kevlar-FRP
}

\author{
Wijanto, S..$^{*}$, Andriono, T. ${ }^{2}$ and Tanudjaja, J.A. ${ }^{3}$
}

\begin{abstract}
Unreinforced Masonry (URM) Walls in old buildings are vulnerable to collapse upon receiving high lateral inertia force in-plane directions due to earthquakes. An experimental study was conducted to investigate the seismic behaviour of these walls. For this purpose, two $75 \%$ URM wall units with a 1/2/2-wythe of solid clay-bricks were constructed in Dutch bond configuration and tested until failure under quasi-static-reversed cyclic loading. Both models were constructed with a door opening using local materials and local labours. They were constantly loaded in vertical direction representing gravity loads of the first floor tributary area of an existing building. Test Unit-1 represented the existing structural condition. Test Unit-2 was similar but strengthened with Kevlar fibre material, installed in the diagonal directions of both wall surfaces, to enhance its shear strength. The results of the study showed that this strengthening technique is promising and can be done with great ease.
\end{abstract}

Keywords: Unreinforced masonry; Dutch bond; seismic; Kevlar fibre.

\section{Introduction}

Masonry buildings were very common from the beginning of civil construction all over the world. Clay bricks have been used for at least 10,000 years. They were made from sun-dried clay and widely used in Babylon, Egypt, Spain, South America, United States, and elsewhere [1]. Older buildings mostly consist of unreinforced masonry (URM) walls. The URM elements are constructed from hand-placed units of natural or manufactured material such as clay-bricks, one stacked on top of another and jointed to each other with mortar. As the properties of clay vary throughout the world, it is apparent that different kinds of bricks predominate in different regions. These wide variety of bricks resulted a bewildering variety of properties.

Most of those older masonry buildings are designed primarily to resist gravity loads only since the provision for earthquake generated loads was not then established.

${ }^{1}$ Principal Director PT. Gistama Intisemesta, Л. Puri Kencana Raya Blok J-1/3B, Jakarta 11610, INDONESIA

Lecturer of Civil Engineering Department, Trisakti University, Л. Kyai Tapa No.1, Jakarta, INDONESIA

${ }_{2}^{2}$ Director PT. Gistama Intisemesta, Л. Puri Kencana Raya Blok J1/3B, Jakarta 11610, INDONESIA

${ }^{3}$ Structural Engineer PT. Gistama Intisemesta, Л. Puri Kencana Raya Blok J-1/3B, Jakarta 11610, INDONESIA

*Corresponding author; Email: s.wijanto1@gistama.com

Note: Discussion is expected before July, $1^{\text {st }} 2021$, and will be published in the "Civil Engineering Dimension", volume 23, number 2, September 2021.

Received 21 December 2020; revised 13 January 2021; accepted 26 January 2021.
The clay brick material is relatively heavy, brittle, of low tensile strength, and shows low ductility when subjected to seismic excitation. From previous earthquake experience, showing the vulnerability of URM buildings, current regulations for construction and design in seismic prone areas throughout the world no longer recommend the use of unreinforced masonry structures. Considerable attention to the means of evaluation and strengthening of older masonry buildings that still exist in seismic prone area is necessary.

The aim of this research was to study the performance of in-plane URM walls with door opening in the centre when subjected to gravity load and lateral seismic action. Another intention of this project was to enhance the seismic performance of URM walls using a strengthening material. The research model was to represent existing URM walls built in Indonesia in the 1900s. The research included two models of URM wall; both models were tested in the Research Institute for Human Settlements laboratory in Bandung-Indonesia. Test Unit-1 was a URM-Wall representing an existing structural condition and Test Unit-2 was strengthened by high performance Kevlar fibre. Kevlar is lighter, stronger, and also has high impact resistance. Both wall test units were tested until failure under quasi-static-reversed cyclic loading.

\section{Material Data}

This section describes the properties of Indonesian masonry units and other materials, which were commonly used in older URM buildings, such as the 
Lawang-Sewu (Thousand Doors) in Semarang, Central Java, Indonesia. The properties of Kevlar material, which is used in this research for strengthening purposes, are also discussed in this section.

\section{Mortar}

The mortar was mixed manually; the cementitious material and the aggregate were being mixed dry until a uniform colour was achieved. The water then was added and shovelled or hoed thoroughly until the mortar was easily workable and the ingredients were thoroughly distributed. The nominal mortar with one part of Portland cement to four parts of sand (in accordance with current Indonesia clay brick code) was used for the mortar joints with an average thickness of $10 \mathrm{~mm}$. Batching the mortar was done by volume, using plastic buckets. Following the ASTM C109-1988 [2] and ASTM C270-1999 [3], a series of tests were conducted and the results of average compressive strength based on cubes of $50 \times 50 \times 50$ $\mathrm{mm}$ at 28 days are $10.61 \mathrm{MPa}$ and the coefficient of variation is $14.23 \%$ [4].

\section{Clay Brick}

The local-bricks were used in the experiment with average dimension of $189 \mathrm{~mm}$ length $\mathrm{x} 90 \mathrm{~mm}$ width $\mathrm{x} 47 \mathrm{~mm}$ thick. Each measuring of length, width, and thickness was carried out at least 3 times from 20 samples with coefficients of variation $1.36 \%, 2.02 \%$, and $3.07 \%$, respectively. This average local-brick unit dimension confirms to represent the $75 \%$ of its clay brick dimension used in the original Lawang-Sewu building. The original clay brick average dimension is $256 \mathrm{~mm}$ length $\mathrm{x} 121 \mathrm{~mm}$ width $\mathrm{x} 53 \mathrm{~mm}$ thick.

Two kinds of compressive strength masonry specimens were tested. The first compressive strength test was conducted according to the Indonesian test standard, SNI 15-2094-1991 [5] and secondly several prismatic-masonry specimens with a total of seven layers were also tested in accordance with ASTM C1314-1998 [6]. Those tests are illustrated in Figure 1. The test was terminated at the first crack. Specimens were tested at the age 28 days.

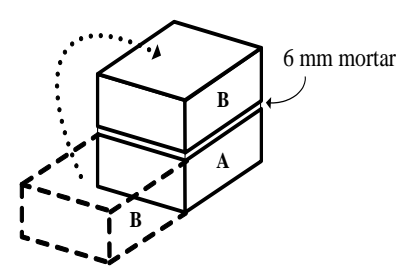

(a)

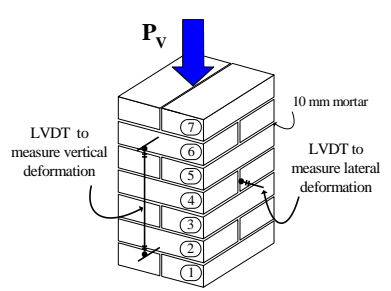

(b)
Figure 1. Clay Brick (a) Compression Strength Test using SNI 15-2094-1991 [5] Method and (b) Prismatic Masonry Specimen using ASTM C-1314-1998 [6]
The average compressive strength of 30 samples based on Indonesian standard is $10.23 \mathrm{MPa}$ with a coefficient of variation $23.15 \%$. The average density of clay-brick test result is $17.493 \mathrm{kN} / \mathrm{m}^{3}$ and the coefficient of variation is $3.86 \%$ [4].

Another compressive strength test of a prismaticmasonry was conducted on 20 samples. The result of average compressive strength based on maximum axial force divided by the top surface area of the specimen is $10.21 \mathrm{MPa}$, with coefficient of variation is $13.68 \%$. This value is quite close to the value obtained from the test result based on Indonesian standard. The average density from the prismatic masonry test result is $18.49 \mathrm{kN} / \mathrm{m}^{3}$ with a coefficient of variation is $4.09 \%$ [4].

Bed joint properties were determined by laboratory testing following the triplet shear test of BS EN 10523 [7]. The samples were assembled in three layered clay brick prisms with $10 \mathrm{~mm}$ mortar joint as shown in Figure 2(a). The shear bond test was conducted after the specimen had reached 28 days age and tested under a combination of direct shear stress and a constant normal stress. A series of average constant normal stress values of $0.01 \mathrm{MPa}, 0.19 \mathrm{MPa}$, and 0.24 $\mathrm{MPa}$ were given and the lateral force was applied incrementally using compression test-machine equipped with a load-cell control (Figure 2(b)).

A regression line was obtained from the graphic plotted average shear strength with respect to the correspondent average normal stress as shown in Figure 3.

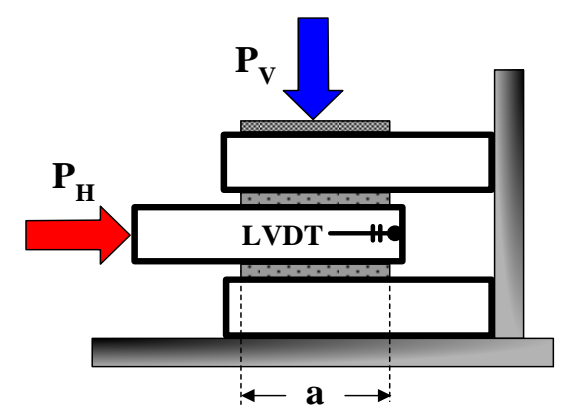

(a)

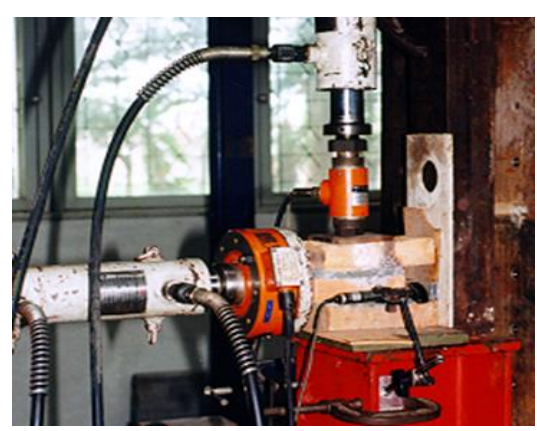

(b)

Figure 2. Shear Strength Test Set Up on Horizontal Triplet Test 


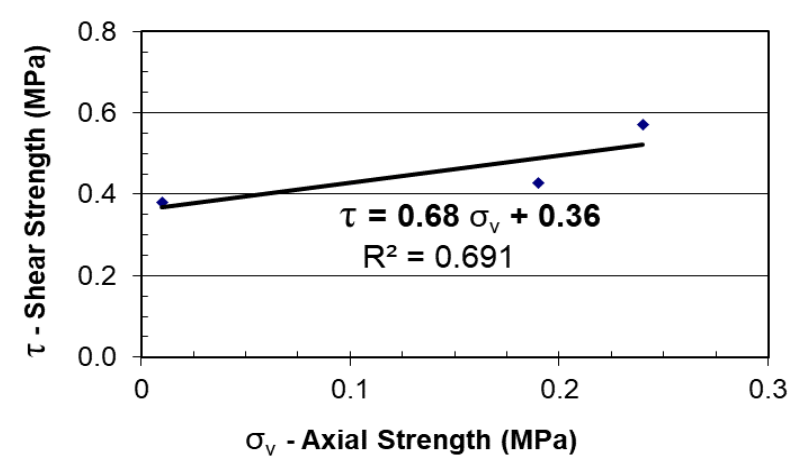

Figure 3. Correlation between Shear Strength vs. Axial Stress and the R-value

The joint shear strength was expressed as a MohrCoulomb type of failure criterion as follows in Equation 1:

$\tau=0.68 \sigma_{\mathrm{v}}+0.36(\mathrm{MPa})$

where $\sigma_{v}$, the axial stress at the bed joint, and $\tau$, the shear strength

Coefficients 0.68 and 0.36 in Equation 1 indicate the friction coefficient, $\mu$, between mortar and masonry unit at a friction angle of $34^{0}$ and the shear bond strength at initial compression equal to zero (cohesion), respectively. It is evidently understood that the shear capacities of masonry joints significantly increase as the normal stress level increases.

The elastic Young's modulus of masonry was determined as the stress-strain diagrams from the compressive strength of prismatic masonry. The average strains obtained by dividing the measured vertical deformations by the corresponding gauge lengths of the recording instruments. Typically, a secant modulus of elasticity, $E_{m e}$, is described in FEMA-274 [8] and NEHRP 2000 [9], by the slope of the line of the stress-strain curve between $5 \%$ and $33 \%$ of the estimated masonry ultimate compressive stress as shown in Figure 4. Based on that prismatic masonry test, the average Young's Modulus, $E_{m}$, of clay-brick is $6567.7 \mathrm{MPa}$ or equivalent to $643.4 f_{m}^{\prime}$ with the coefficient of variation is $46.63 \%$. The shear modulus of elasticity, $G_{m}$, was taken 0.4 times $E_{m}$.

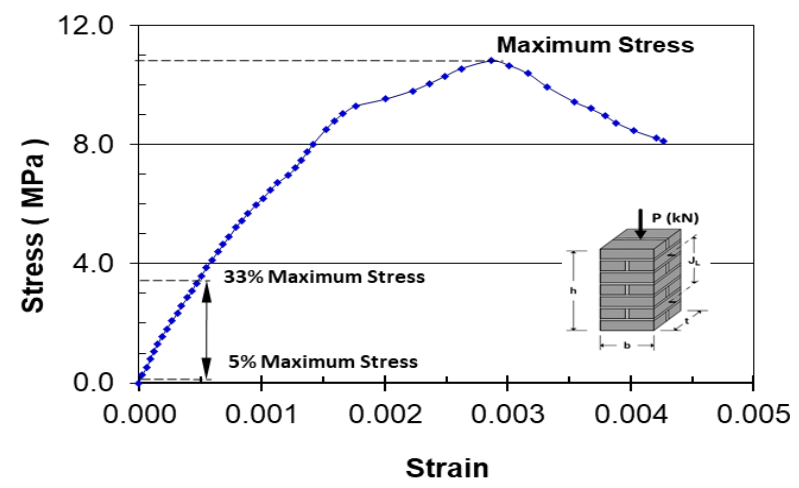

Figure 4. Measured Young's Modulus based on FEMA-274 [8]
Poisson's ratio test results from several prismaticmasonry specimens gave a range value between 0.25 -0.46 . Hilsdorf [10] found the Poisson's ratio of brick prisms about 0.2 at the initial loading stage and increased to about 0.35 before the ultimate load was reached. In this research the Poisson's ratio value was taken as 0.25 .

\section{Stone Foundation}

The compressive strength of stone foundation material was achieved by testing 7 samples were made respectively measuring $400 \mathrm{~mm}(l) \times 400 \mathrm{~mm}(w) \mathrm{x}$ $800 \mathrm{~mm}(h)$. Compressive strength test was conducted after the specimens have reached 28 days age. The result of average compressive strength, $f_{s}$, of stone foundation is $7.00 \mathrm{MPa}$. Based on that prismatic stone test, the average Young's Modulus, $E_{s}$, of stone specimen is $8168.4 \mathrm{MPa}$ and the shear modulus, $G_{s}$, was taken as $0.4 E_{s}=3267 \mathrm{MPa}$. The average density of stone material is $21.307 \mathrm{kN} / \mathrm{m}^{3}$.

\section{Kevlar Fibre}

High performance Kevlar fibre was applied as a strengthening material for URM walls. Kevlar is sold in Indonesia under the market name of Renderoc FR10 and manufactured by PT. Fosroc Indonesia. This material is lighter, stronger and also has high impact resistance compared with other materials such as aluminium, glass or carbon fibre. Tensile strength of Renderoc FR10 is about 5 times that of steel, 3 times that of nylon, and 2.5 times that of polyester. Physical properties of the Kevlar material type AK40 according to manufacturer's data are as shown in Table 1.

Table 1. Properties of Kevlar Fibre AK40

\begin{tabular}{ll}
\hline Properties & Value \\
\hline Breaking Strength & $400 \mathrm{kN} / \mathrm{m}$ \\
Fibre Quantity & $280 \mathrm{gram} / \mathrm{m}^{2}$ \\
Thickness & $0.193 \mathrm{~mm}$ \\
Design of Tensile Strength & $2,100 \mathrm{MPa}$ \\
Design of Elastic Modulus & $120,000 \mathrm{MPa}$ \\
Design of Maximum Strain & $1.8 \%$ \\
\hline Note: Design value means guarantee value.
\end{tabular}

Nitobond-EP10P and Nitobond-EC were used when applying the Kevlar material to the masonry walls. Nitobond-EP10P is effective for priming all masonry wall surfaces where Kevlar sheet will be applied. The following specification is presented in Table 2.

Table 2. Properties of Nitobond-EP10P

\begin{tabular}{ll}
\hline Properties & Value \\
\hline Adhesion Strength & $8.5 \mathrm{~N} / \mathrm{mm}^{2}$ \\
Compressive Strength & $80 \mathrm{~N} / \mathrm{mm}^{2}$ \\
Tensile Strength & $15 \mathrm{~N} / \mathrm{mm}^{2}$ \\
Modulus Elasticity & $16 \mathrm{kN} / \mathrm{mm}^{2}$ \\
Shrinkage & $\leq 0.1 \%$ linear \\
\hline
\end{tabular}


Nitobond-EC is an adhesive compound and has a specifically formulated epoxy resin adhesive for bonding between Nitobond-EP10P and Kevlar sheet.

\section{Experimental Programs}

\section{Test Models and Instrumentation}

Two URM-Walls at $75 \%$ scale were erected in the laboratory with a masonry wall thickness of a $1 \frac{12}{2}$ wythe clay-brick and arranged in Dutch bond configuration, generally used at the time of construction of the prototype. As shown in Figure 5(a), Test Unit-1 was a URM wall representing an existing structural condition and Figure 5(b), Test Unit-2, was the similar URM wall strengthened by Kevlar fibre.

\section{Loading Sequences}

Two types of design load were applied for both URM Wall units. First, it was the vertical load simulating the gravity load from the existing building and second, it
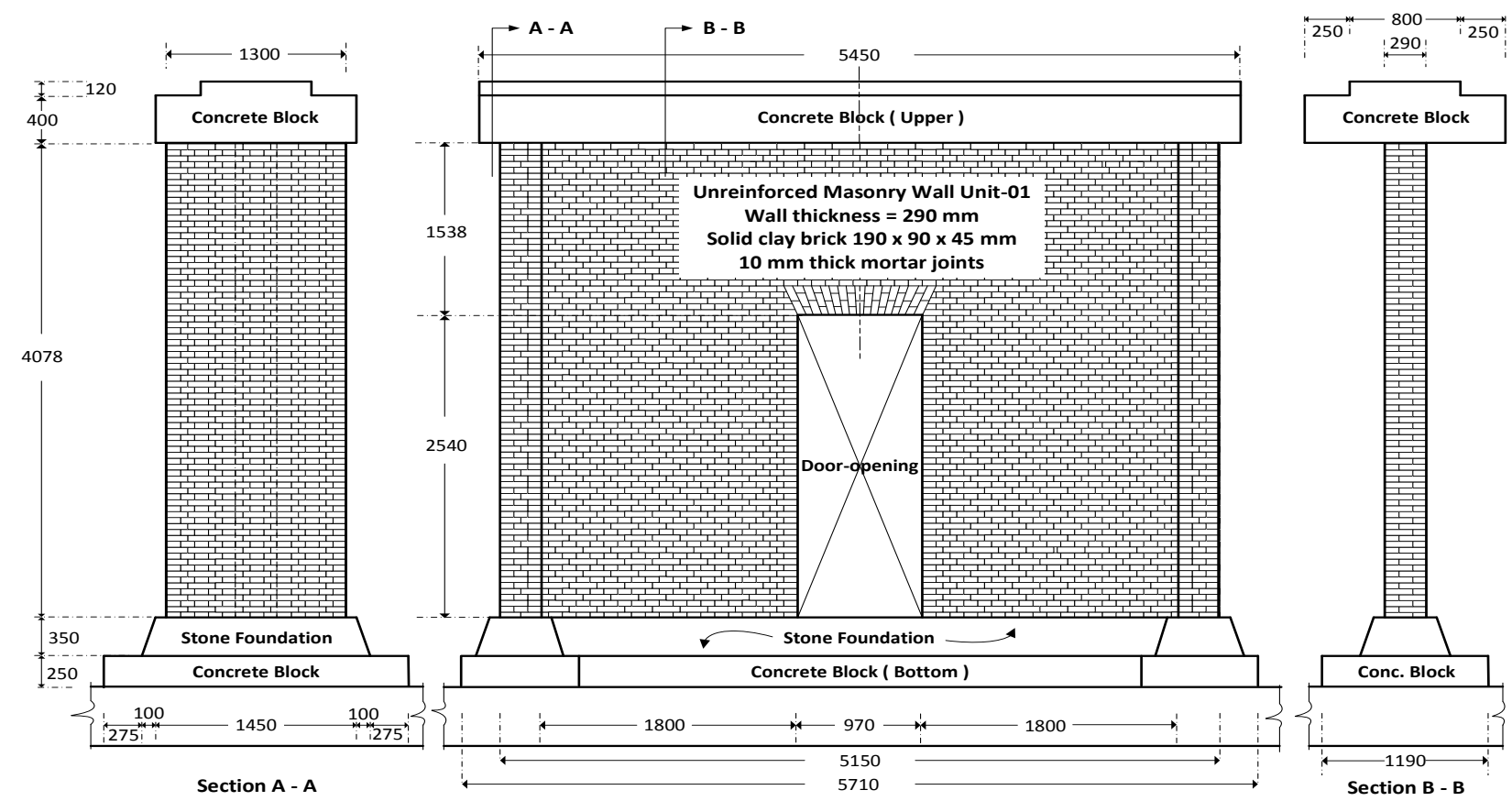

(a)
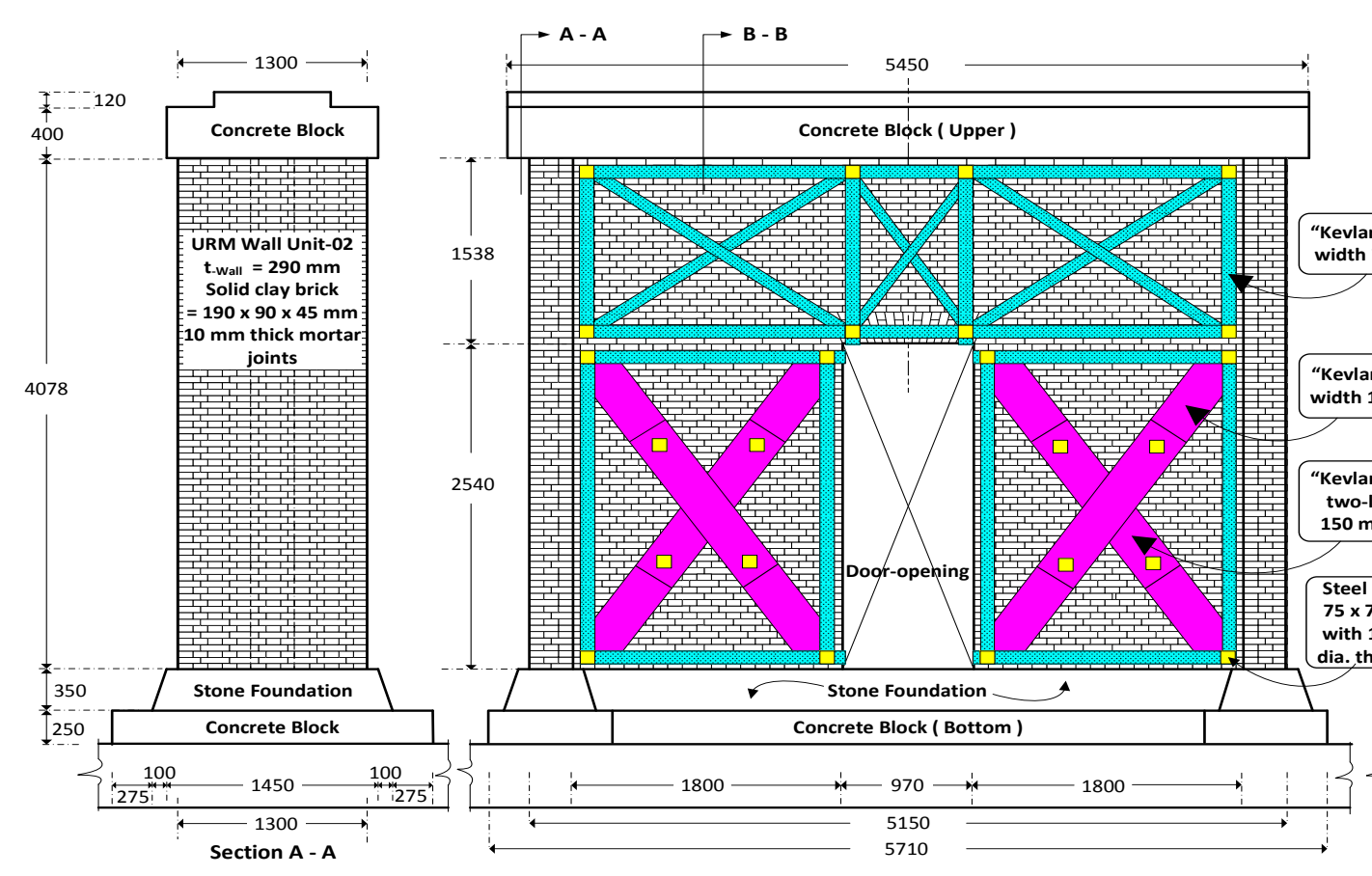

250 i $800 \longrightarrow \vec{i} 250$

(b)

Figure 5. Prototype of URM-Wall (a) Test Unit-1 and (b) Test Unit-2 (unit in mm) 
was the lateral in-plane load representing the lateral earthquake inertia load. The simulated gravity load was applied up to the designed value of $0.25 \mathrm{MPa}$ at the top surface of URM Wall Test Unit-1. The load came through four pairs of VSL thread lock bars plus the weight of the top concrete beam, as shown in Figure 6(a). Each pair of VSL thread lock bars provided $109 \mathrm{kN}$ pretension forces and was measured with load cells. This vertical load was kept as constant load during the test.

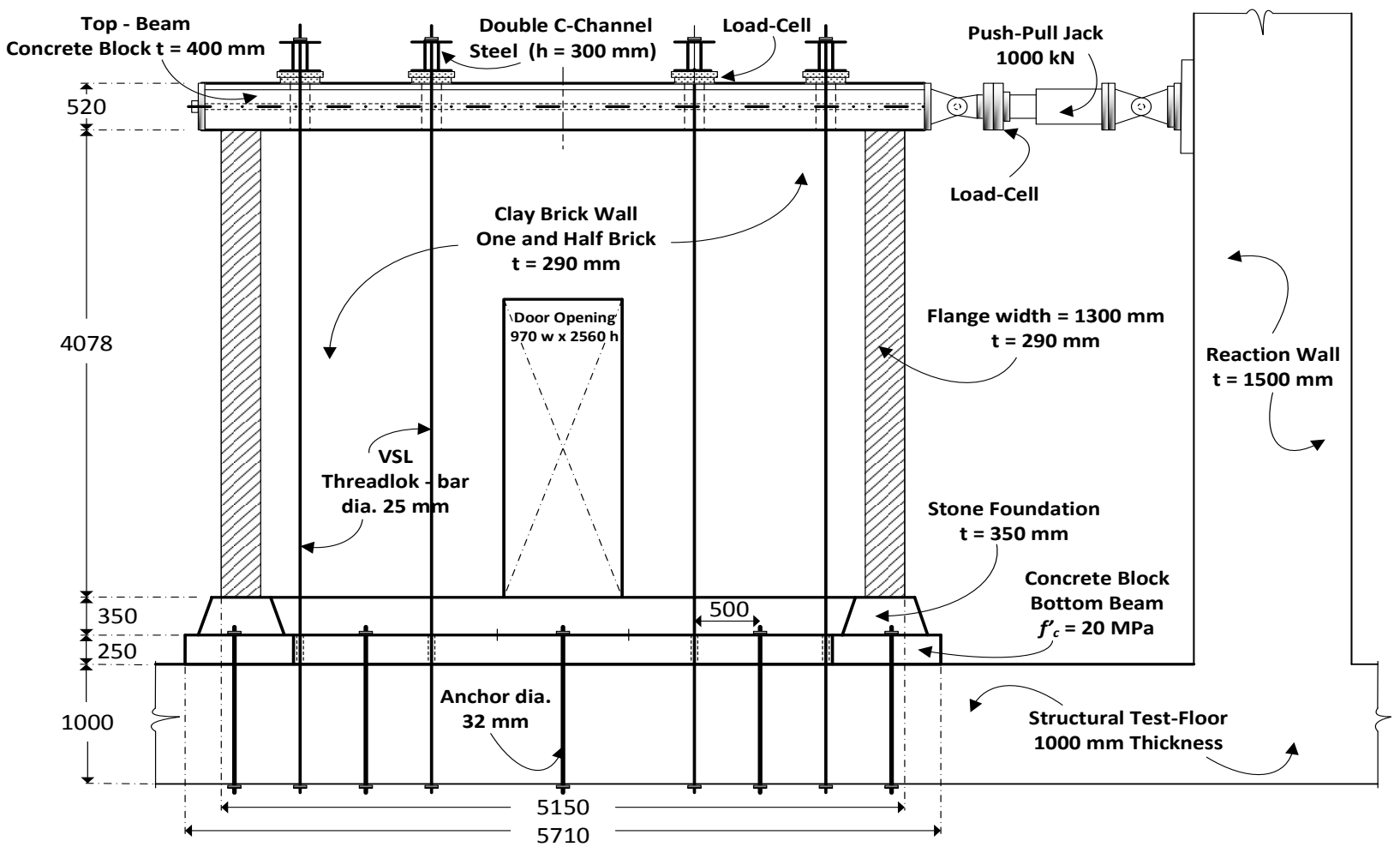

(a)

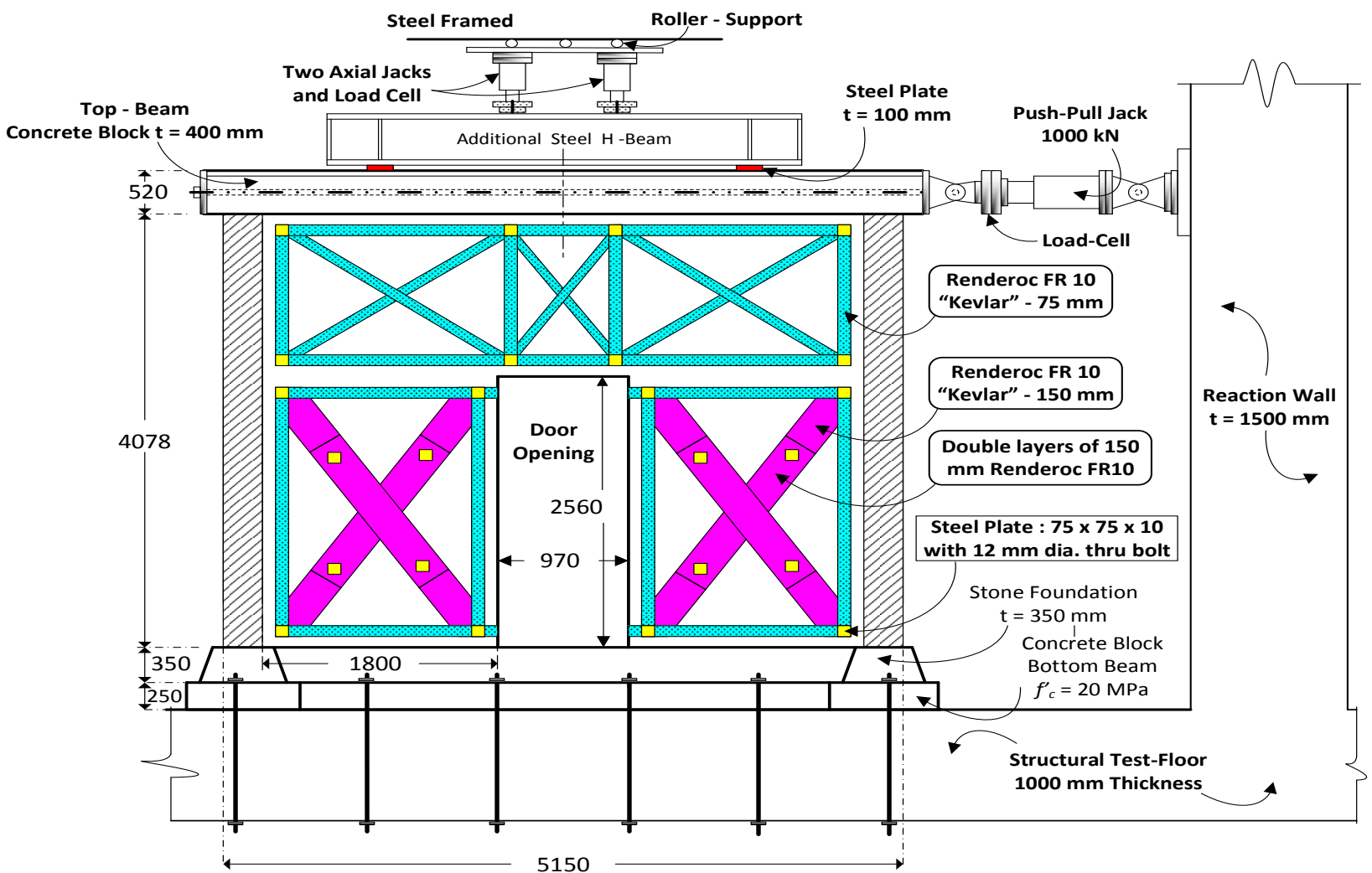

(b)

Figure 6. Section and Detail Experimental Model of (a) URM-Wall Test Unit-1 and (b) URM-Wall Test Unit-2 (unit in mm) 
A pair of axial jacks on top of each load cell was utilized for Test Unit-2 and replaced the four pairs of VSL thread lock bars that used in Test Unit-1 (see Figure 6(b)). These axial jacks and load cells were applied on top of the top concrete beam through very stiff steel beams that will give a uniform stress at the top surface of URM Wall Test Unit-2. These axial jacks were connected to a single hydraulic pump unit to ensure a constant load at all times until the testing is completed. The reason for using a pair of axial jacks on the Test Unit-2 was to get a better constant normal stress compared to the previous system since with the jacks any minor uneven changes of normal stress due to the horizontal displacements could be corrected with ease.

The lateral loading history of testing the URM wall unit was carried out in a series of cyclic lateral load reversals by increasing the top lateral displacement of the URM-Wall. The first cycles of lateral loading history were applied in each direction with force control. The lateral force was increased gradually with increment of approximately $49 \mathrm{kN}$ for each loading step until reaching the maximum top displacement of $1 \mathrm{~mm}$ for positive direction. It continued to other reversal direction and followed with the displacement control for the next cycles. Two complete cycles of lateral loading were applied at every escalation of the top lateral displacement of the URM wall specimen. Test sequences of cyclic load for Test Unit-1 and Test Unit-2 were shown in Figure 7. The loading was carried out until the specimen unit failed, which means that the specimen could no longer carry the lateral load. Therefore, the elastic response, the first yield, the maximum capacity, and the collapse position were determined directly based on the test results.

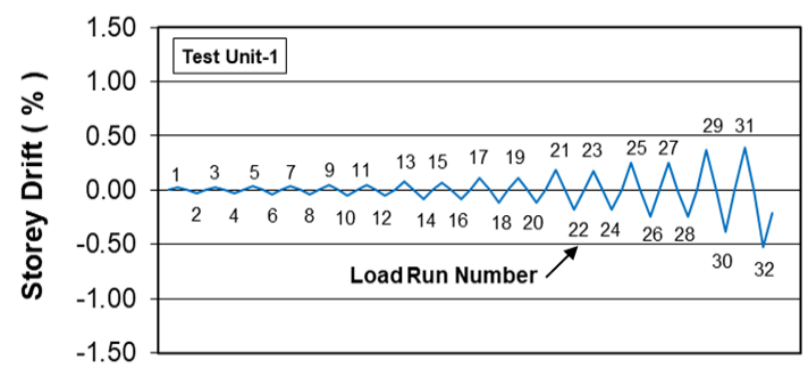

(a)

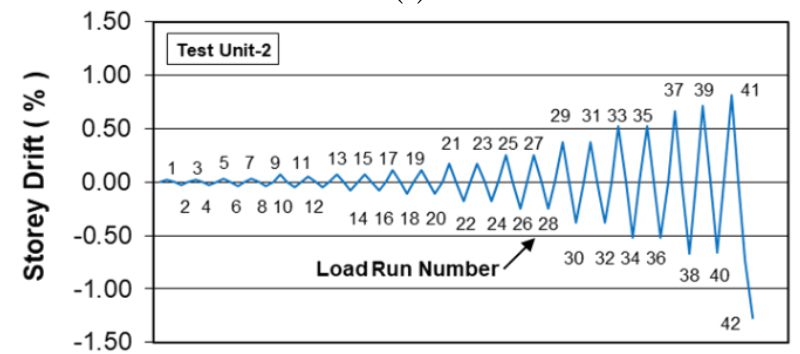

(b)

Figure 7. Test Sequence of Cyclic Load for (a) Test Unit-1 and (b) Test Unit-2
As described earlier, the Unit-1 model was constructed to represent a URM-wall at $75 \%$ scale with

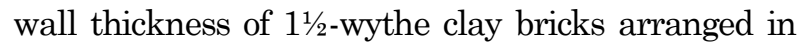
Dutch bond configuration. The wall was perforated with a door opening and $1300 \mathrm{~mm}$ length of flanged walls on both edges. The URM-wall was constructed above the stone foundation as shown in Figure 8(a). The Kevlar layers were applied diagonally on both sides of the URM Wall Test Unit-2 as shown in Figure 8(b).

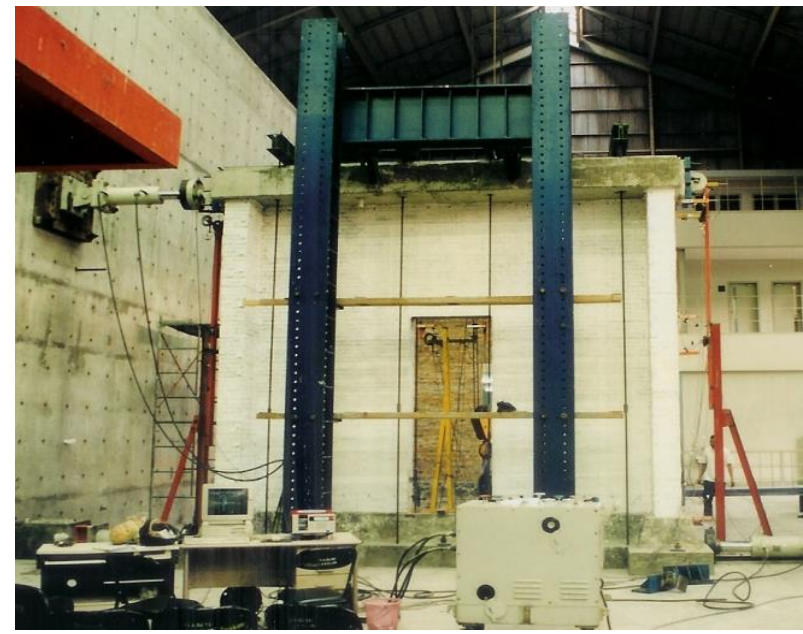

(a)

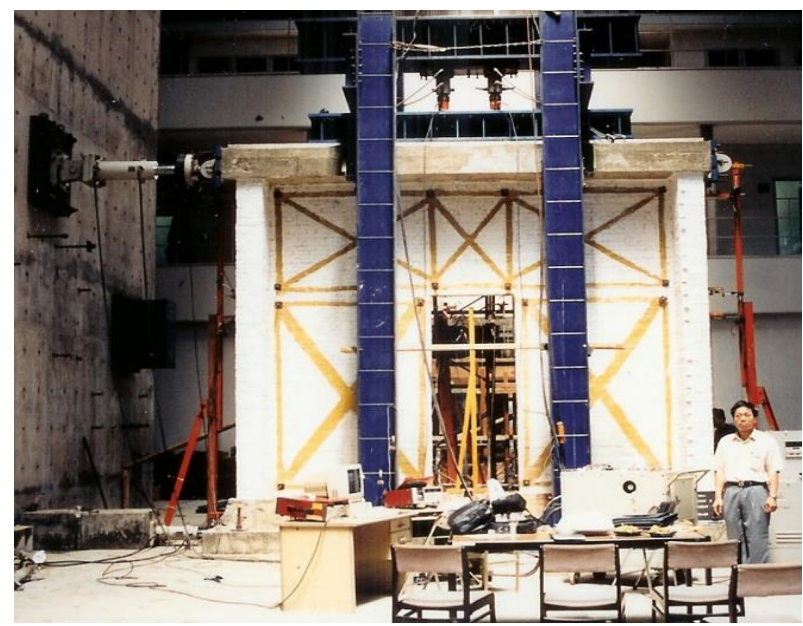

(b)

Figure 8. Test Arrangement of (a) URM Wall Test Unit-1 and (b) URM Wall Test Unit-2 with Diagonal Kevlar Fibre on Both Surfaces

\section{Test Results}

\section{Test Unit-1}

An overview of the final crack pattern after the test of URM Wall Test Unit-1 was as shown in Figure 9. The crack pattern was shown in black and red line colour represented cracks caused by the push and pull lateral loading condition, respectively.

The final stage of the test occurred at the pull lateral load cycle 32 . The maximum top lateral displacement 
was recorded at -21.26 mm and the lateral load was $333 \mathrm{kN}$. The shear failure at the web of left pier wall was sudden, cracking sounds were heard and involved a big shear crack. Cracks also happened at the right spandrel above the right pier wall and continued to the flanged wall. At this final stage, the shear crack on the right pier-wall was not closed anymore. The test was discontinued because of the instability of the URM-Wall and retrofitting could not be carried out for this specimen.

The overall response of the URM-Wall Test Unit- 1 is summarized in the hysteresis loop for lateral force versus top displacement or storey drift value as shown in Figure 10. It is of interest to note that the wall responded linearly with a high stiffness for the first stage at lower storey drift. After reaching a new maximum deflection, the URM-Wall responded in the next cycle for the same storey drift value with a reduced stiffness. Subsequent cycles indicated that some strength loss might have taken place. The positive maximum lateral force was recorded $416 \mathrm{kN}$ at cycle number 11 with $+7.695 \mathrm{~mm}$ top lateral displacement $(0.189 \%$ storey drift). In the reversed direction of loading, the maximum lateral force was recorded $369 \mathrm{kN}$ at cycle number 11 with $-7.135 \mathrm{~mm}$ top lateral displacement ( $0.175 \%$ storey drift).
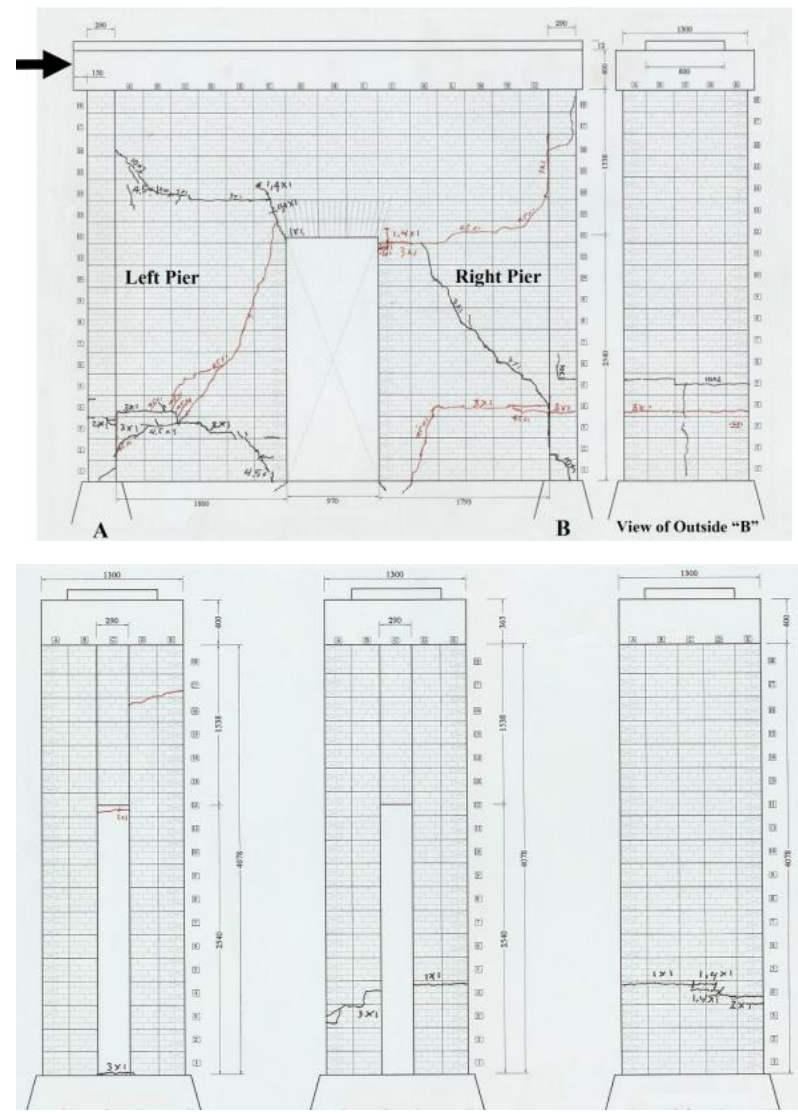

Figure 9. Crack Pattern of Test Unit-1 on Laboratory Test

Note: Black colour means cracking by the push lateral load and red colour means cracking by the pull lateral load.

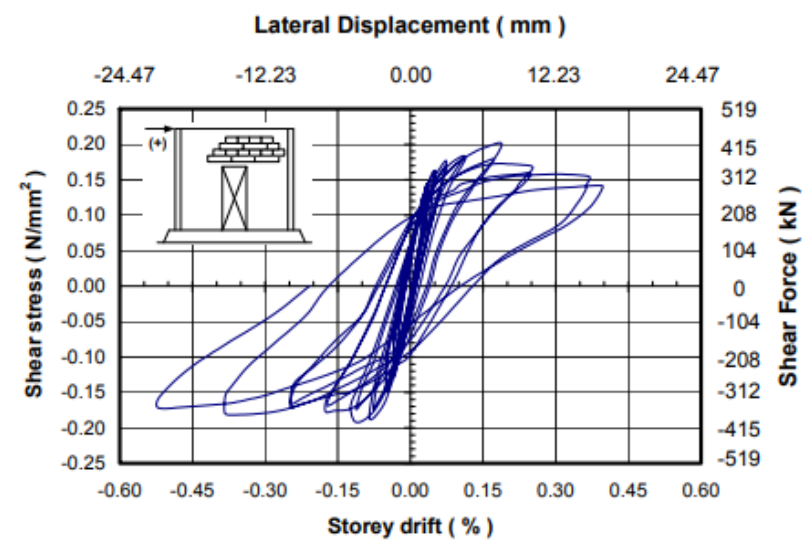

(a)

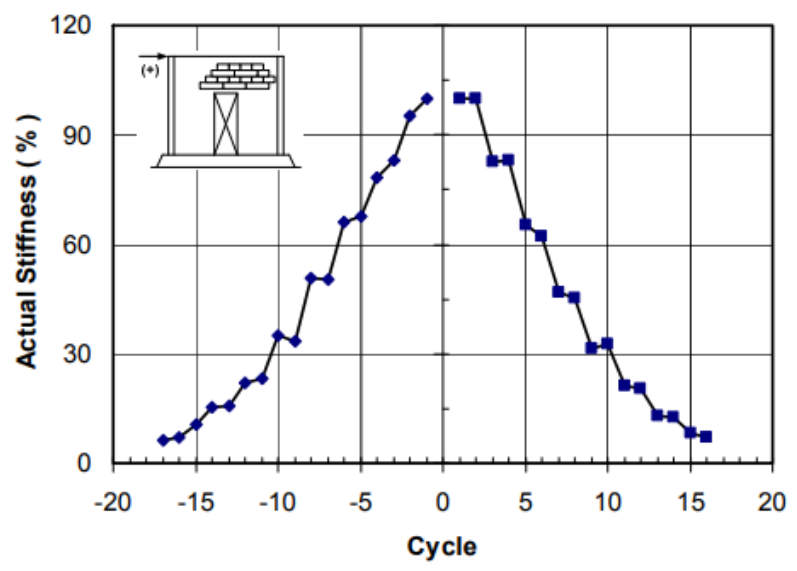

(b)

Figure 10. (a) Hysteresis Loop and (b) Secant Stiffness Degradation of URM-Wall Test Unit-1

It was observed from this test result that there were significant shear failure damages on both piers and the wall had limited capacity to resist shear forces. Propagation cracks were spreading through the horizontal and vertical mortar and also through the solid brick. It may be concluded if an existing URM building located in a seismic prone area is hit by a strong ground excitation it might experience a significant damage, which would almost be impossible to repair. Therefore its seismic resistance needs to be assessed as to whether it would still behave elastically during a certain level of ground excitation. Improvement or strengthening is mandatory, if the seismic demand exceeds its elastic capacity.

\section{Test Unit-2}

In order to obtain a better performance of URM Walls, Kevlar fibre composite layers were used in this study for strengthening the URM Wall Test Unit-2. The perforated URM Wall Test Unit-2 with door opening was divided into three rigid bodies, i.e. the upper part of the door opening and two pier-walls adjacent to the door opening. The Kevlar layers were applied diagonally on both sides of the URM Wall Test Unit2 as shown in Figure 5(b). The same pattern of loading was then applied to this URM Wall Test Unit-2. URM 
Wall Test Unit-2 responded very well during the testing and the influence of the strengthening could be seen fairly clearly by the increased capacity of the unreinforced masonry wall in resisting the lateral shear load. It was clear the performance of URM Test Unit-2 during the test was dominated by a rocking mode. The final crack pattern after the test was shown in Figure 11.

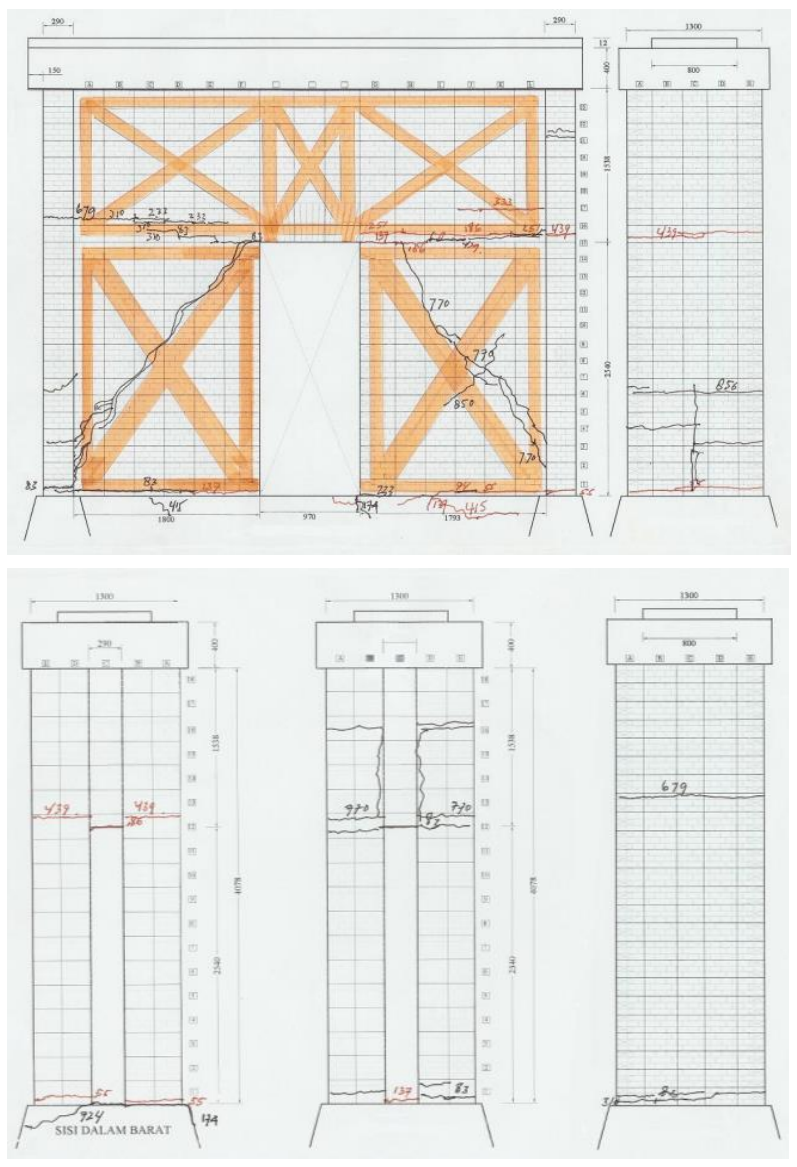

Figure 11. Crack Pattern of Test Unit-2 on Laboratory Test

At the early loading stages, the flexural cracks were initiated at the bed joints in between the first and the second courses at the lower part of both piers, and also above the pier head below the spandrel beam. Then the cracks spread horizontally along the bed joint and allowed for a rocking motion of both piers. Flexural cracking started at the top lateral displacement of $1.40 \mathrm{~mm}$, i.e. cracking start at the bed joint between the first and the second course at the lower part of the right pier and extended to the right flanged wall. Horizontal bed joint cracks were also observed between the first and the second course at the lower part of the left pier and extended to the left flanged wall at the next cycle where the lateral top displacement was $+2 \mathrm{~mm}$. At the next top lateral movement, bed joint cracking on the lower part of the left pier penetrated to the stone-foundation. These cracks led to a rocking mechanism, where the bed joint cracks developed along the interface of the bottom and top of both piers. The URM Wall Test Unit-2 was divided into three rigid bodies, i.e. the upper part of the door opening and two piers adjacent to the door opening. These rocking mechanisms occurred continuously following the increasing top lateral displacement.

Cracking of the Kevlar layer started from the weakened area surrounding the bolt anchor placement where the anchor bolts were drilled into the Kevlar sheets and also penetrated the thickness of the URM Wall at every corner. It was initially observed at the bottom of the spandrel beam side on top of the right pier. The maximum positive lateral force was recorded at $536 \mathrm{kN}$ at load run number 31 with the top lateral displacement was $+33.19 \mathrm{~mm}(0.816 \%$ storey drift). It was much higher when compared to URM Wall Test Unit-1 which was only $416 \mathrm{kN}$. The breaking of the left upper part of the 'Kevlar' layer at the left pier-wall from its anchor-bolt caused further cracking (see Figure 11). The Kevlar layer also delaminated from the surface of the URM Wall. The maximum lateral load resistance of URM Wall Test Unit-2 was $-699 \mathrm{kN}$ with a maximum lateral displacement up to $-29.49 \mathrm{~mm}$ and then the lateral load decreased to $-168.5 \mathrm{kN}$ but the top lateral displacement increased to $-51.69 \mathrm{~mm}$ due to large tensile cracking on the diagonal part of the left pier-wall. The failure was sudden, and the diagonal tension crack in the middle of the left pier was measured at $36 \mathrm{~mm}$ width. It was the end of the test, which was discontinued because of the potential instability of the URM-Wall.

The overall response of the URM-Wall Test Unit-2 is summarized in the hysteresis loop for lateral force versus top displacement of the URM wall or storey drift value as shown in Figure 12(a). Shear force vs. storey drift response of URM Wall Test Unit-2 up to load run number 11 that gave storey drift value $=$ $+0.11 \%$ or top lateral displacement $+4.5 \mathrm{~mm}$. It is of interest to note that the stiffness in the positive direction (push lateral load) is much less than the other direction until load run number 17 that top lateral displacement value was $+21 \mathrm{~mm}(0.517 \%)$. A probable reason is no uniformity of the brick material and also the brick masonry workmanship.

The wall responded linearly with a high stiffness for the first cycle at low storey drift and reduced in stiffness for the next cycle for the same storey drift value. After reaching a new maximum deflection, the URM-Wall responded in the next cycle with a reduced stiffness. Subsequent cycles indicated that some strength loss might have taken place. The final stage of the test occurred when the negative lateral load cycle was recorded at $-699 \mathrm{kN}$ with a maximum top lateral displacement $-29.49 \mathrm{~mm}$ ( $0.725 \%$ storey drift) and measured to $-51.69 \mathrm{~mm}$ with negative lateral load 
decreased to $-168.5 \mathrm{kN}$. While both maximum positive and negative lateral forces were still satisfactory, the Kevlar fibre was torn off near the bolt joint triggered the diagonal tension cracks on the clay brick units at both piers and reduced the shear capacity of the pier instantly. The hysteretic curves show a bilinear behaviour with a softening part when the rocking crack was open, the hysteretic loops showed noticeable pinching and indicated limited energy dissipation availability.

Propagation of cracks during cyclic loading caused the stiffness degradation of the URM-Wall Test Unit-2. It was also occurred when the cycle repeated for the same storey drift value. The cyclic stiffness could be defined as the slope of the line joining the origin and the peak value of the respective cycle. The stiffness degradation of every cycle could be plotted as shown in Figure 12(b). The ordinate represents the ratio between the stiffness at a particular cycle with respect to the first cycle. The stiffness reduction between initial storey drift values was ranging from $8 \%$ to $40 \%$. The stiffness dropped drastically up to $40 \%$ at Cycle +5 or load run number 9 . The lateral load value was similar with the previous cycle but the top displacement increased significantly from the target displacement $+2 \mathrm{~mm}$ to become $+2.79 \mathrm{~mm}$. It is observed that rocking failure was happening when bed joint cracks at the bottom and top left pier were extended along the pier-wall length.

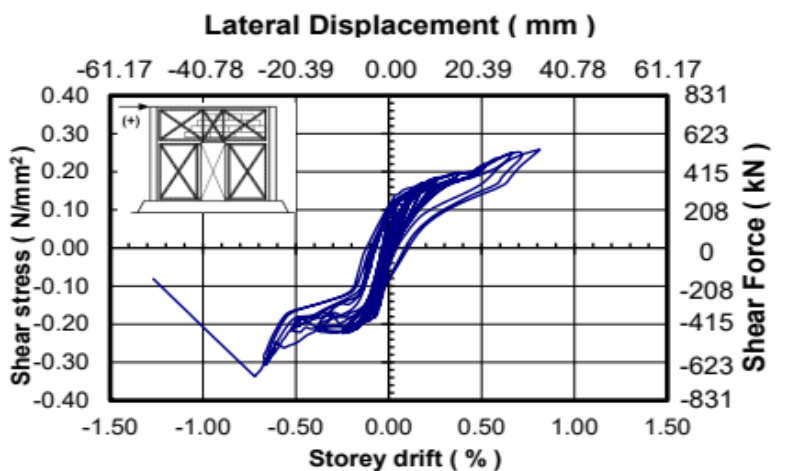

(a)

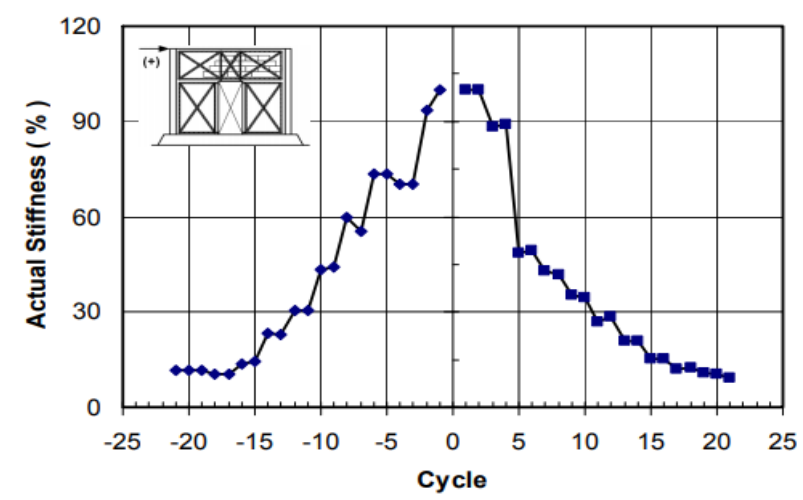

(b)

Figure 12. (a) Hysteresis Loop and (b) Secant Stiffness Degradation of URM-Wall Test Unit-2
It was found from the test result that external application of Kevlar fibre material at both faces of the URM Wall Test Unit-2 demonstrated:

- Improved the in-plane capacity of URM Wall Test Unit-2. The lateral resistance was enhanced by about $75 \%$ when compared to Test Unit-1.

- Localized and significantly reduced crack patterns. Bed joint cracks just occurred outside the Kevlar application area.

- The maximum drift up to $0.814 \%$ was measured at the final cycle.

- The configuration of Kevlar fibre which was applied to the URM Wall Test Unit-2 changed the performance of both piers from a shear mode to a rocking mode before the Kevlar fibre started tearing from the existing bolt holes and along the fibre direction at the higher lateral loading and reduced the diagonal tensile capacity of both piers drastically.

\section{Conclusions}

An experimental study was carried out with two test units of Unreinforced Masonry Walls. The first unit was meant to represent a wall in an existing building, whereas the second one was tested after strengthened with Kevlar Fibre material. These specimens seem to be the largest of its kind, which have ever been tested to study the seismic behaviour of traditional masonry walls with a door opening in Indonesia. Some conclusions can be drawn based on these test results as follows:

1. Based on the Test Unit-1 test result, it is most likely that existing URM buildings, located in seismic prone areas, might experience severe shear failure damage when the demand lateral seismic forces exceeds its capacity. Therefore the seismic resistance of these walls need to be assessed as to whether they would still behave elastically during a certain level of ground excitation.

2. The configuration of Kevlar fibre, which was applied at both surfaces to the URM Wall Test Unit-2, improved the performance of both piers of the wall. The failure mechanism changed from a shear mode to a rocking mode and it can also be concluded that Kevlar fibre strengthening technique is promising and can be installed with great ease without much change the heritage of original architectural building.

3. With appropriate arrangements and maximised the strength capacity of Kevlar fibre, a practicing engineer will be able to obtain a desired rocking mechanism in the masonry structure and it can also significantly increase the in-plane URM wall capacity. 


\section{References}

1. Drysdale, R.G., Hamid, A.A., and Baker, L.R., Masonry Structures: Behaviour and Design, Prentice-Hall, Englewood Cliffs, N.J., 1994.

2. ASTM C109-1988, Compressive Strength of Hydraulic Cement Mortars, American Society for Testing and Materials, West Conshohocken, Pa, 1988.

3. ASTM C270-1999, Specification for Mortar for Unit Masonry, American Society for Testing and Materials, West Conshohocken, Pa, 1999.

4. Wijanto, L.S., Seismic Assessment of Unreinforced Masonry Walls, $\mathrm{PhD}$ thesis, Department of Civil Engineering, University of Canterbury, New Zealand, 2007, $188 \mathrm{p}$.

5. SNI 15-2094-1991, Bata Merah Pejal untuk Pasangan Dinding, Standar Nasional Indonesia, Badan Standardisasi Nasional, Indonesia, 1991.
6. ASTM C1314-1998, Standard Method for Constructing and Testing Masonry Prisms Used toDetermine Compliance with Specified Compressive Strength of Masonry, American Society for Testing and Materials, West Conshohocken, Pa, 1998.

7. BS EN 1052-3:2002, Methods of Test for Masonry, British Standards Insitution, United Kingdom, 2002.

8. FEMA 274, NEHRP Commentary on The Guidelines for The Seismic Rehabilitation of Buildings, Federal Emergency Management Agency, Washington, D.C., 1997.

9. NEHRP 2000, NEHRP Recommended Provisions for Seismic Regulations for New Buildings and Other Structures, BSSC, Washington, D.C., 2000.

10. Hilsdorf, H.K., An Investigation into the Failure Mechanism of Brick Masonry Loaded in Axial Compression, in Designing, Engineering and Constructing with Masonry Products, ed. F.B. Johnson, 1967. 